\title{
Study of Cluster Anions Generated by Laser Ablation of Titanium Oxides: A High Resolution Approach Based on Fourier Transform Ion Cyclotron Resonance Mass Spectrometry
}

\author{
Nicolas Barthen, ${ }^{1}$ Eric Millon, ${ }^{2}$ Frédéric Aubriet ${ }^{1}$ \\ ${ }^{1}$ Laboratoire de Spectrométrie de Masse et de Chimie Laser, Institut Jean Barriol Fédération de Recherche 2843, Université \\ Paul Verlaine-Metz 1, Boulevard Arago Metz Technopôle, F-57078 Cedex 03, France \\ ${ }^{2}$ GREMI, UMR 6606-CNRS, Université d'Orléans, Orléans, France
}

\begin{abstract}
Laser ablation of titanium oxides at $355 \mathrm{~nm}$ and ion-molecule reactions between $\left[\left(\mathrm{TiO}_{2}\right)_{\mathrm{x}}\right]^{\bullet}$ cluster anions and $\mathrm{H}_{2} \mathrm{O}$ or $\mathrm{O}_{2}$ were investigated by Fourier transform ion cyclotron resonance mass spectrometry (FTICR MS) with an external ion source. The detected anions correspond to $\left[\left(\mathrm{TiO}_{2}\right)_{x}\left(\mathrm{H}_{2} \mathrm{O}\right)_{y} \mathrm{OH}\right]^{-}$and $\left[\left(\mathrm{TiO}_{2}\right)_{x}\left(\mathrm{H}_{2} \mathrm{O}\right)_{\mathrm{y}} \mathrm{O}_{2}\right]^{-\bullet}$ oxy-hydroxide species with $\mathrm{x}=1$ to 25 and $\mathrm{y}=1,2$, or 3 and were formed by a two step process: (1) laser ablation, which leads to the formation of $\left[\left(\mathrm{TiO}_{2}\right)_{\mathrm{x}}\right]^{-\bullet}$ cluster anions as was previously reported, and (2) ion-molecule reactions during ion storage. Reactions of some $\left[\left(\mathrm{TiO}_{2}\right)_{x}\right]^{-\bullet}$ cluster anions with water and dioxygen conducted in the FTICR cell confirm this assessment. Tandem mass spectrometry experiments were also performed in sustained off-resonance irradiation collision-induced dissociation (SORI-CID) mode. Three fragmentation pathways were observed: (1) elimination of water molecules, (2) $\mathrm{O}_{2}$ loss for radical anions, and (3) fission of the cluster. Density functional theory (DFT) calculations were performed to explain the experimental data.
\end{abstract}

Key words: Laser ablation, Ion-molecule reaction, FTICR MS, DFT calculations, Cluster ions, Titanium oxy-hydroxide anions

\section{Introduction}

$\mathrm{T}$ itanium oxides and, more specifically, $\mathrm{TiO}_{2}$, have been utilized in many applications. They may be used as catalysts for the photochemical degradation of hydrocarbons

Electronic supplementary material The online version of this article (doi:10.1007/s13361-010-0040-5) contains supplementary material, which is available to authorized users.

Correspondence to: Frédéric Aubriet; e-mail: aubriet@univ-metz.fr
$[1-5]$, as gas sensors $[6,7]$, or may be associated with electronic or optoelectronic devices $[3,8]$. $\mathrm{TiO}_{2}$ is a wide band-gap semiconductor with n-type charge carriers. Recently, it was demonstrated that sub-oxides $\mathrm{TiO}_{2-x}$ $(0<x<1)$ compounds are p-type semiconductors [6]. One method to prepare $\mathrm{TiO}_{2-\mathrm{x}}$ titanium oxide thin film is the socalled pulsed-laser deposition (PLD) technique, which is based on the laser ablation of a solid target. This process induces the production of gas-phase species, which ensures the growth of a thin film on the substrate. In the case of metal oxides, the stoichiometry of the deposited material could be controlled and adjusted by means of a reactive 
oxygen atmosphere and/or by adjusting the fluence (energy per surface unit) of the laser focused on the target. The oxygen deficiency in $\mathrm{TiO}_{2-\mathrm{x}}$ compounds is mainly caused by the presence of trivalent titanium ions. Though the growth process on the substrate is of prime importance for controlling the composition and the structural properties of PLD films, the laser ablation step and the expansion dynamics of the plasma plume also play a major role. Consequently, it appears important to increase the knowledge of laser interaction with titanium oxides. In general, the interaction of a laser beam with a non-metallic solid induces different processes, which lead to the expulsion of neutral and ionized species into the gas phase. Haglund proposed a qualitative description of these processes for inorganics, which begins with the assumption that laser sputtering can be broken down into four phases: (1) the absorption of laser energy by one- or multiple-photon processes (hence, absorption properties of the solid phase sample are consequently of major importance); (2) the conversion of the incident energy through radiative and non-radiative relaxation processes; (3) the ejection of species, such as atoms, molecules, neutrals, ions, excited species, from the irradiated surface; and (4) the formation and the expansion of a more or less dense plume of neutrals and ions [9]. The characterization of the emitted species from the ablated material in the laser plume is more particularly of fundamental interest. Techniques such as temporally and spatially resolved optical spectroscopy [10] and laser induced fluorescence [11] are largely used for this purpose. However, optical emission spectroscopy and laser-induced fluorescence are limited to a small number of species, i.e., atoms and dimers. Gas-phase reactions between small transition metal [12-17] species and, more specifically, titanium metals [18] formed by laser ablation and dioxygen have been studied. After reaction in the gas phase, the resulting species were condensed with argon on a cold CsI window before being analyzed by infrared spectroscopy. Only a small quantity of $\mathrm{M}_{\mathrm{x}} \mathrm{O}_{\mathrm{y}}$ species were evidenced and characterized. Alternatively, mass spectrometry coupled to laser ablation (LA-MS) provides information on atomic and cluster species present in the gas phase. When considering the ionic fraction of species ejected in vacuum under laser irradiation, relevant information may be obtained on the atomic and high mass cluster species present in the gas phase above the target after laser-matter interactions [19-21].

In the present study, we investigate the processes associated with the reaction of the ionic species produced by LA of titanium oxides with water and dioxygen in the gas phase by mass spectrometry.

The nature and the distribution of anions observed by LA of $\mathrm{TiO}_{2}, \mathrm{Ti}_{2} \mathrm{O}_{3}$, and $\mathrm{TiO}$ are first presented and compared. The results obtained by tandem mass spectrometry (MS/MS) are then reported before investigating the reactivity of some selected cluster anions with water and oxygen. Finally, quantum chemistry results are given to elucidate some structures and to investigate the distribution of the charge and the spin density, which aids in the analysis of experimental data.

\section{Experimental}

\section{Samples}

Three common titanium oxides, i.e., $\mathrm{TiO}, \mathrm{Ti}_{2} \mathrm{O}_{3}$, and $\mathrm{TiO}_{2}$, were investigated in this study. $\mathrm{TiO}(99.9 \%), \mathrm{Ti}_{2} \mathrm{O}_{3}$ (99.95\%), and $\mathrm{TiO}_{2}$, also known as rutile $(99.95 \%)$, were provided by Inland Europe, (Conflans sur Lanterne, France) and were analyzed as received (sputtering pellets) without further purification or treatment.

\section{Mass Spectrometry}

The instrument utilized in these experiments was a laser ablation ionization FT-ICR-MS (IonSpec, Varian Corporation, Palo Alto, CA, USA) equipped with a shielded 9.4 Tesla superconducting magnet (Cryomagnetics, Oak Ridge, TN, USA). Mass spectra were acquired in the negative detection mode. The external ProMALDI card was used to perform the experiments reported in this study. The samples were fixed on a stainless steel holder before being introduced in the external laser ion source. The residual pressure in the target region was $\sim 5 \times 10^{-4}$ Torr $\left(\sim 6.7 \times 10^{-2} \mathrm{~Pa}\right)$. An ORION air-cooled Nd:YAG laser (wavelength $=355 \mathrm{~nm}$, pulse duration $=5 \mathrm{~ns}$, maximum output energy $=8 \mathrm{~mJ}$ ) was used to produce ions by laser ablation. The laser fluence ranged from 0.9 to $2.2 \mathrm{~J} / \mathrm{cm}^{2}$. The irradiated area was approximately $0.2 \mathrm{~mm}^{2}$. After each laser pulse, the sample stage was moved such that the ions were generated from a fresh (not previously ablated) target area. The ions resulting from eight successive laser-sample interactions were stored in a rfonly hexapole before being transferred to the FTICR cell, in which the background pressure was $2 \times 10^{-10}$ Torr $\left(2.7 \times 10^{-8} \mathrm{~Pa}\right)$. The ions were thermalized during accumulation in the storage hexapole with $\mathrm{N}_{2}$ introduced by a pulsed valve opened for $1.8 \mathrm{~s}$. The ion guide, i.e., a hexapole in rf-only mode, between the LA external source and the FTICR cell was tuned to allow ions in the $200-1500 \mathrm{~m} / \mathrm{z}$ range to be efficiently transferred into the FTICR MS cell. To ensure the efficient transfer of the largest mass cluster ions, the amplitude of the rf was increased from $\sim 200 \mathrm{~V}$ to $\sim 350 \mathrm{~V}$. The ions were trapped in the ICR cell by a $0.2 \mathrm{~V}$ trapping potential and were then excited by the application of an arbitrary excitation-specific wave function on the excitation plates. The resulting image current was detected, amplified, digitized, apodized (Blackman) and Fourier-transformed to produce a mass spectrum. The obtained mass accuracy was typically $<1 \mathrm{ppm}$, and the mass resolution at $m / z 500$ was close to 150,000 . To confirm the assignments, the experiments were conducted with very high mass resolution $(1,000,000$ at $m / z$ 707.5137). 
MS/MS measurements were performed in sustained offresonance irradiation collision-induced dissociation (SORICID) mode. First, the parent ions were mono-isotopically isolated. The kinetic energy of the parent ion was then increased by off-resonance excitation. Simultaneously, $\mathrm{N}_{2}$ was introduced in the cell. The collisions of excited ions with nitrogen gas partially converted the kinetic energy into internal energy, which induced dissociation [22]. $\mathrm{N}_{2}$ was introduced into the FTICR MS with a pulsed valve opened for $10 \mathrm{~ms}$ during the offset excitation, which was applied for $250 \mathrm{~ms}$. The frequency offset was systematically taken as $1.5 \%$ of the parent ion secular frequency. The experiments were repeated five times, and the abundance of the ions was normalized to the total ion current (TIC).

Ion-molecule reactions in the gas phase were performed in the FTICR MS cell. After isolation of the reactant ion, small quantities (some ppm) of water and dioxygen in nitrogen were introduced with a pulsed valve (opening time: $50 \mathrm{~ms}$, tank pressure: $70 \mathrm{mTorr}$, reservoir feeding: $\mathrm{N}_{2}$ and $\sim 250 \mathrm{ppm}$ of $\mathrm{H}_{2} \mathrm{O}$ and $\mathrm{O}_{2}$ ). After a given reaction time, the resulting ions were excited and detected. The nature and the distribution of the products were studied as functions of reaction time, i.e., the time between the introduction of the reactive neutral species and the onset of the excitation step for detection. The majority of the ion-molecule reactions were performed with $\left[\left(\mathrm{TiO}_{2}\right)_{\mathrm{x}}\right]^{-}$anions that were not initially detected, but formed by MS/MS of selected precursor cluster ions.

\section{Computational Methods}

DFT calculations were performed for several of the anions observed in this study to form a hypothesis of their possible structures. The calculations were performed using the Gaussian 03 suite [23] at the B3PW91 level of theory with LanL2DZ basis and the triple zeta + polarization (TZVP) 6$311+\mathrm{G}(2 \mathrm{~d}, \mathrm{p})$ basis. The geometry optimization, binding energy, and frequencies (plus zero-point energy correction) were calculated by the B3PW91 using the LanL2DZ basis first and the TZVP basis second to reduce the time of the geometry optimization with the triple zeta + polarization basis.

\section{Results and Discussion}

The results obtained for bivalent, trivalent, and tetravalent titanium oxides are first presented and discussed. The dependency of the titanium oxide stoichiometry on the detected anions distribution is reported. MS/MS experiments were conducted on representative species of the different cluster anion families. The study of the ion-molecule reaction in the gas phase is then developed to elucidate ion formation processes involving reactions between $\left[\left(\mathrm{TiO}_{2}\right)_{\mathrm{x}}\right]^{\bullet}$ species and $\mathrm{H}_{2} \mathrm{O}$ and $\mathrm{O}_{2}$. The last section gathers the calculated structures of some representative anions of this study. DFT calculations explain the processes by their formation, dissociation and reaction with small molecules in the gas phase.

\section{Analysis of TiO, $\mathrm{Ti}_{2} \mathrm{O}_{3}$, and $\mathrm{TiO}_{2}$ by $\mathrm{LA}$-FTICR MS}

Figure 1 displays a representative mass spectrum related to $\mathrm{TiO}_{2}$. Anions obeying the general formula $\left[\mathrm{Ti}_{3-18} \mathrm{O}_{8-39} \mathrm{H}_{2-7}\right]^{(\cdot)}$ were detected in the $200-1500 \mathrm{~m} / \mathrm{z}$ range. The parameters used to obtain the mass spectrum reported in Figure 1 led to a low mass cutoff at $m / z \sim 200$. Therefore, smaller ions were not efficiently transferred to the FTICR MS cell. The high mass accuracy measurement allowed a global formula to be assigned to each obtained signal. The assignment was confirmed by comparison of the experimental and theoretical isotopic pattern. Indeed, titanium presents five isotopes, which lead to very specific isotopic distributions as a function of the number of titanium atoms in the investigated cluster anion.

A simple method for describing the different cluster anions has been previously proposed [13, 22]. These anions consist of a combination of building blocks (BB) and charge carriers (CC). This notation is too simplistic to structurally describe the observed cluster ions, but it is a simple and efficient way to distinguish the different series of anions, which behaved differently in the MS/MS experiment. According to this formalism, $\mathrm{TiO}_{2}$ and $\mathrm{H}_{2} \mathrm{O}$ were considered as $\mathrm{BB}$, while $\mathrm{OH}^{-}$and $\mathrm{O}_{2}{ }^{-\bullet}$ were the two main CC. Other $\mathrm{CC}$ were additionally evidenced, but their contributions to the TIC were not significant. The nature of the BB was chosen for two main reasons: (1) they were proposed in previous works [24], and (2) titanium, oxygen, and hydrogen atoms adopt common oxidation states. Differing by the $\mathrm{CC}$, two anion series may be distinguished: $\left[\left(\mathrm{TiO}_{2}\right)_{\mathrm{x}}\left(\mathrm{H}_{2} \mathrm{O}\right)_{\mathrm{y}} \mathrm{OH}\right]^{-}$ and $\left[\left(\mathrm{TiO}_{2}\right)_{\mathrm{x}}\left(\mathrm{H}_{2} \mathrm{O}\right)_{\mathrm{y}} \mathrm{O}_{2}\right]^{-*}$. The number of $\mathrm{H}_{2} \mathrm{O}$ BB generally ranged from 1 to 3 and was not ion cluster size-dependent. The mass spectrum in Figure 1 revealed 3 to $18 \mathrm{TiO}_{2} \mathrm{BB}$ in the cluster anions. The radical behavior of the "super oxide" series will be demonstrated and confirmed in the last section by considering the spin density of the calculated structures. Moreover, $\left[\left(\mathrm{TiO}_{2}\right)_{\mathrm{x}}\left(\mathrm{H}_{2} \mathrm{O}\right)_{\mathrm{y}} \mathrm{O}_{2}\right]^{-\bullet}$ radical species must also be considered as a reduced species for which one titanium atom is trivalent, whereas in $\left[\left(\mathrm{TiO}_{2}\right)_{x}\left(\mathrm{H}_{2} \mathrm{O}\right)_{y} \mathrm{OH}\right]^{-}$all of the titanium atoms are thought to be tetravalent.

The relative distribution of the different anion series as a function of the number of both $\mathrm{H}_{2} \mathrm{O}$ and $\mathrm{TiO}_{2}$ sub-units was also investigated. An additional graphic is given in Supplementary Information 1. The variation of cluster anion relative abundance was found to be lower than $10 \%$ for all species and was generally smaller than 5\% for intense species (five replicates of eight laser shots). Thermalization of the ions in the ion source seems to favor the stability of the signal. The relative amplitude was calculated by taking into account the isotopic pattern and not only the "mono-isotopic" ion. This data treatment avoids the introduction of a bias associated with the progressive splitting of ion abundance into the different contributions of the isotopic distribution when the number of $\mathrm{TiO}_{2} \mathrm{BB}$ increases. Indeed, the abundance of the 


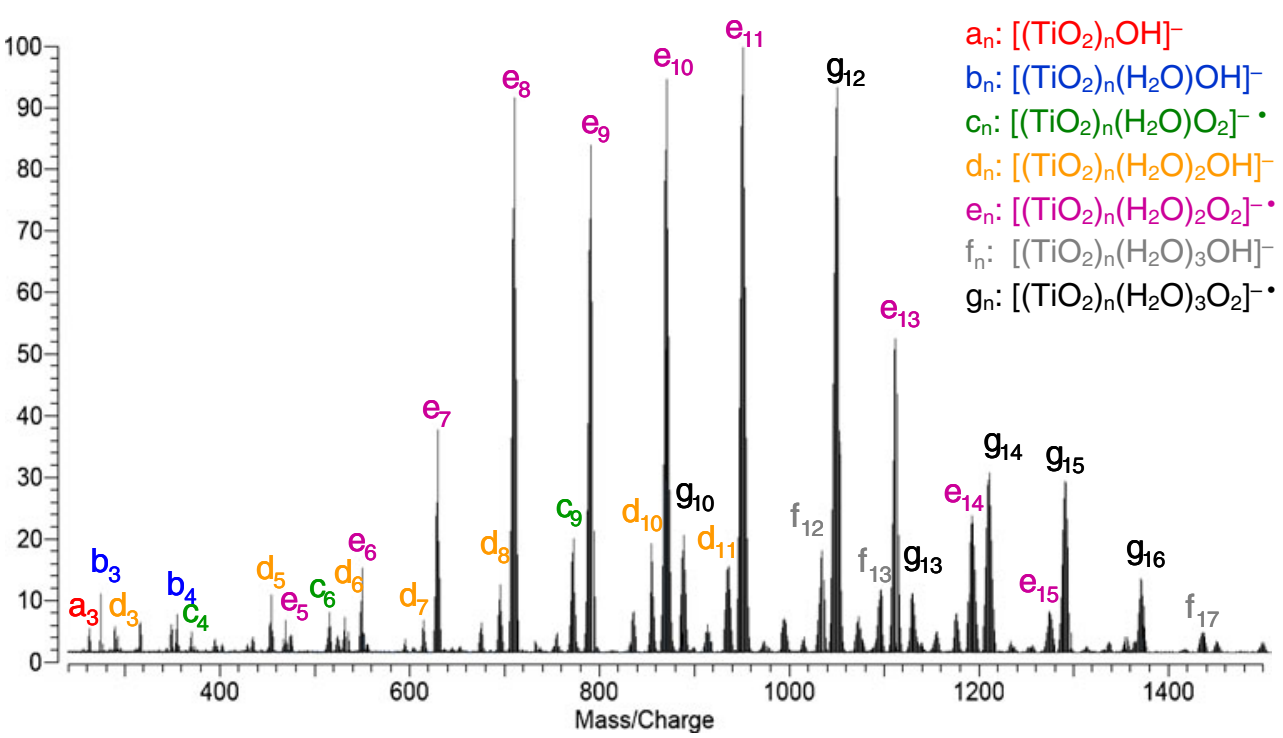

Figure 1. Negative ion mass spectrum of $\mathrm{TiO}_{2}$ obtained by LA-FTICR MS with an external laser ion source at $355 \mathrm{~nm}$. The detected ions are indexed with a letter and a number. The letter is associated with the nature of the anion series with the number of the $\mathrm{TiO}_{2}$ units

"mono-isotopic" peak of $\left[\left(\mathrm{TiO}_{2}\right)_{18}\left(\mathrm{H}_{2} \mathrm{O}\right)_{2} \mathrm{OH}\right]^{-}$at $\mathrm{m} / \mathrm{z}$ 1490.9123 corresponds to less than $12 \%$ of the whole isotopic pattern, whereas it represents more than $40 \%$ for $\left[\left(\mathrm{TiO}_{2}\right)_{3}\left(\mathrm{H}_{2} \mathrm{O}\right)_{2} \mathrm{OH}\right]^{-}$at $\mathrm{m} / \mathrm{z}$ 292.8377. Regardless of the $\mathrm{CC}$ and $\mathrm{TiO}_{2}$ BB numbers, the cluster anions never accommodated more than $3 \mathrm{H}_{2} \mathrm{O}$ moieties. These results are not consistent when comparing them with a previous study concerning cerium oxy-hydroxide anions [25]. Aubriet et al. showed that the number of $\mathrm{H}_{2} \mathrm{O}$ moieties increases with the cluster anion size, i.e., the number of $\mathrm{CeO}_{2}$ BB. The same tendency was observed for aluminum and silicon oxy-hydroxides [26-29]. Consequently, the behavior of titanium $\left[\mathrm{Ti}_{3-18} \mathrm{O}_{8-39} \mathrm{H}_{2-7}\right]^{(\cdot)-}$ anions appears to be highly specific and deserves to be more specifically studied. Some trends were found to be common in both studies, for example, the relative distribution of reduced/non-reduced species with respect to the number of $\mathrm{MO}_{2} \mathrm{BB}$ (with $\mathrm{M}=\mathrm{Ti}$ or $\mathrm{Ce}$ ). For a $\mathrm{MO}_{2} \mathrm{BB}$ number smaller than 7 , reduced and non-reduced species have a similar abundance. In contrast, the intensity of the reduced species increased relative to those of the nonreduced species for anions with more than $7 \mathrm{MO}_{2} \mathrm{BB}$. This may be associated with the propensity of large species to accommodate unpaired electrons.

A surprising experimental result observed in the study of titanium oxides by LA-FTICR MS was the erratic development of cluster anions as a function of the number of $\mathrm{TiO}_{2}$ and $\mathrm{H}_{2} \mathrm{O}$ BB. More specifically, the different combinations of both identified $\mathrm{BB}$ were not systematically detected regardless of the investigated cluster anion family, i.e., ion with the same number of $\mathrm{TiO}_{2} \mathrm{BB}$. The examination of consecutive cluster anions, separated successively by one $\mathrm{TiO}_{2} \mathrm{BB}$, led to different patterns when the distribution of cluster anions with respect to the second, i.e., $\mathrm{H}_{2} \mathrm{O}$, $\mathrm{BB}$ was examined. As an example, $\left[\left(\mathrm{TiO}_{2}\right)_{7} \text { and } 9\left(\mathrm{H}_{2} \mathrm{O}\right)_{1,2,3} \mathrm{OH}\right]^{-}$anions were detected, whereas combinations with 1 or $2 \mathrm{H}_{2} \mathrm{O}$ molecules were only observed for the $\left[\left(\mathrm{TiO}_{2}\right)_{8}\left(\mathrm{H}_{2} \mathrm{O}\right)_{\mathrm{y}} \mathrm{OH}\right]^{-}$ anion family. Some explanations will be tentatively given in further sections.

In general, the nature of the detected cluster anions was the same for each of the three investigated titanium oxides (see Supplementary Information 2). The cluster ion series highlighted for titanium dioxide were also observed for both titanium monoxide and titanium sesquioxide. However, the relative distribution of $\left[\left(\mathrm{TiO}_{2}\right)_{\mathrm{x}}\left(\mathrm{H}_{2} \mathrm{O}\right)_{\mathrm{y}} \mathrm{OH}\right]^{-}$and $\left[\left(\mathrm{TiO}_{2}\right)_{\mathrm{x}}\left(\mathrm{H}_{2} \mathrm{O}\right)_{\mathrm{y}} \mathrm{O}_{2}\right]^{-\bullet}$ cluster ions did not vary depending on the investigated oxide. This result was surprising when comparing previous LA-MS data of these same compounds [24, 30-32].

The behavior of $\mathrm{TiO}, \mathrm{Ti}_{2} \mathrm{O}_{3}$, and $\mathrm{TiO}_{2}$ observed by LA time of flight mass spectrometry (LA-TOF-MS) [24, 30-32] or LA-FTICR MS $[19,24]$ with an internal ion source or at very low pressure with an external ion source highlighted a sample-dependent behavior. All previous works demonstrated the ability of LA to generate a large number of cluster ions with small quantities of hydrogen atoms. The main components of these ions may be considered as a combination of $\mathrm{TiO}_{2} \mathrm{BB}$ with $\mathrm{OH}^{-}, \mathrm{O}_{2}^{-}$, or $\mathrm{TiO}^{-} \mathrm{CC}$ to yield $\left[\left(\mathrm{TiO}_{2}\right)_{\mathrm{x}} \mathrm{OH}\right]^{-},\left[\left(\mathrm{TiO}_{2}\right)_{\mathrm{x}} \mathrm{O}_{2}\right]^{-\bullet}$, and $\left[\left(\mathrm{TiO}_{2}\right)_{\mathrm{x}} \mathrm{TiO}\right]^{-\bullet}$ anions, respectively [24]. $\left[\left(\mathrm{TiO}_{2}\right)_{\mathrm{x}}\right]^{-\bullet}$ anions were also observed. Some poorly abundant cluster ions, including a $\mathrm{H}_{2} \mathrm{O}$ BB, were also detected. The distribution of cluster anions, including a given number of titanium atoms and different numbers of oxygen atoms, has been correlated to the oxidation number of the studied titanium oxide. This has been used to define the oxidation state of titanium in various samples [19]. In contrast, the mass spectra obtained in this study clearly indicated that the detected species and the relative distribution were not sample dependent. All titanium atoms in the detected cluster anions must be considered as 
tetravalent regardless of the considered ion and the investigated titanium oxide. The sole exception was associated with radical anions, for which one titanium atom was expected to be trivalent. Both 266 and $355 \mathrm{~nm}$ wavelengths were used in previous studies, and only restricted differences were observed, which means that LA of titanium oxides at these wavelengths was not dramatically affected. A more significant difference between this study and previous ones was the pressure of the LA ion source. In the present work, the pressure is higher by 2 or 3 order of magnitude than in previous experiments, which may have significantly affected and modified the nature of the detected species by mass spectrometry. Considering laser ablation is not affected by the MS devices, it may be proposed that the cluster anions observed in this study were formed by a two-step process. In a first step, titanium/oxygen neutral or ionic species were ejected in the gas phase by laser ablation and reacted in approximately $2 \mathrm{~s}-$-i.e. the storage time- with water and/or dioxygen in the hexapole storage chamber at a $\sim 5 \times 10^{-4}$ Torr background pressure. This may explain the "systematic" tetravalent chemical state of titanium in the different cluster ions. Indeed, the +IV oxidation number is the more stable oxidation state of titanium. This explanation was recently proposed to account for the differences observed in the comparative study of $\mathrm{CeO}_{2}$ by LA coupled to FTICR MS with an external ion source and TOF-MS [25]. In addition, the different time frame of both analyzers (FTICR and TOF) must also be considered to explain the observed differences. For TOF-MS, the ions are rapidly extracted from the ion source, which limits the reactive phenomena between the produced ions and small gas-phase species, such as water or dioxygen. In contrast, the FTICR analyzer favors the most stable species and ensures observation of ions produced by gas-phase processes. This was previously evidenced for other inorganic compounds such, as alkaline and alkalineearth chromate compounds [33, 34]. Nevertheless, the mass spectra obtained by FTICR MS with external or internal ion sources were found to be dramatically different, which supports the predominance of the ion source effect on the observed differences as opposed to the instrument effect.

\section{Tandem Mass Spectrometry Measurements}

MS/MS experiments in SORI-CID mode have been systematically conducted for all of the detected anions regardless of the number of both $\mathrm{CC}$ and $\mathrm{H}_{2} \mathrm{O}$, and $\mathrm{TiO}_{2} \mathrm{BB}$. For each experiment, the mono-isotopic parent ion selection was performed to activate the parent ion by collision. A few examples will be given and fully discussed in this section.

Table 1 shows the results obtained when anions involving 3 $\mathrm{TiO}_{2} \mathrm{BB}$ were activated regardless of the number of $\mathrm{H}_{2} \mathrm{O} \mathrm{BB}$ or the nature of the $\mathrm{CC}$. It is important to note that consecutive fragmentation channels may not be observed in the SORI-CID activation mode. Indeed, the off-resonance excitation only involves the parent ion. After formation, the daughter ions were relaxed to prevent further fragmentation. In some very specific cases, consecutive fragmentation may occur if the internal energy of the daughter ions is still high enough to allow other bonds to be broken. The main fragmentation pathway is the systematic elimination of the water molecule. At higher activation energies, the elimination of $\mathrm{O}_{2}$ or $\mathrm{OH}^{*}$ was observed, which involved the reduction of one titanium atom in the $\left[\left(\mathrm{TiO}_{2}\right)_{3}\left(\mathrm{H}_{2} \mathrm{O}\right)_{0-1} \mathrm{OH}\right]^{-}$precursor ion. For these anions and especially for charged species involving a small number of $\mathrm{TiO}_{2} \mathrm{BB}$, fission of the cluster anions was observed and led to the formation of species including 1 or $2 \mathrm{TiO}_{2} \mathrm{BB}$ and $\mathrm{OH}^{-}$as the CC.

The behavior of larger species, i.e., $\left[\left(\mathrm{TiO}_{2}\right)_{6-12}\left(\mathrm{H}_{2} \mathrm{O}\right)_{1-3} \mathrm{O}_{2}\right]^{\bullet}$ and $\left[\left(\mathrm{TiO}_{2}\right)_{6-12}\left(\mathrm{H}_{2} \mathrm{O}\right)_{1-3} \mathrm{OH}\right]^{-}$, was found to be partly comparable to that observed for small species. The elimination of water and $\mathrm{O}_{2}$ molecules were also observed. As an example, Figure 2 reports the results of the MS/MS experiment performed on the $\left[\left(\mathrm{TiO}_{2}\right)_{11}\left(\mathrm{H}_{2} \mathrm{O}\right)_{2} \mathrm{O}_{2}\right]^{-\bullet}$ cluster anion at an $\mathrm{E}_{\mathrm{COM}}=0.08 \mathrm{eV}$ (energy in the center of mass frame). Both the elimination of water moieties and $\mathrm{O}_{2}$ were observed. The gradual increase of the $\mathrm{E}_{\mathrm{COM}}$ led to an increase in the efficiency of the fragmentation pathway associated with the formation of the reduced $\left[\left(\mathrm{TiO}_{2}\right)_{11}\right]^{-}$anion; however, the elimination of $\mathrm{TiO}_{2} \mathrm{BB}$ was never observed in that case. This is a general trend for all the investigated ions (see Supplementary Information 3) with more than $6 \mathrm{TiO}_{2} \mathrm{BB}$.

The case of cluster anions with 4 or $5 \mathrm{TiO}_{2} \mathrm{BB}$ is more specific. Indeed, the main fragmentation pathway is associated with the simultaneous elimination of $\mathrm{H}_{2} \mathrm{O}$ and $\mathrm{TiO}_{2}$ BB. This may be well explained by considering the structure of cluster ions with three titanium atoms. It will be presented in the last section that these species are highly symmetric and compact. In contrast, both Ti4 and Ti5 cluster anions have structures with one or two dangling titanium atoms associated with oxo or hydroxide groups. These dangling groups are thought to be easily eliminated by MS/MS even under very low activation energies.

The $\mathrm{E}_{\mathrm{COM}}$ that was required to observe the elimination of water molecule(s) was high enough to consider that MS/MS caused hydroxyl group condensation instead of the removal of weakly bound water molecules. This was more specifically supported by the results reported in the literature discussing the investigation of alumina [26-27], silica [29], chromia [35, 36], or ceria [25] oxyanions and oxy-hydroxide anions. A portion of the oxy-hydroxide cluster anions was obtained by the ion-molecule reaction in the gas phase between metal oxide ions and water molecules, which involves the (1) incorporation of "water" in the cluster ion, and (2) formation of hydroxyl groups. In the context of the MS/MS experiments, the elimination of water molecules may be considered as a dehydration process. As a consequence, it was confirmed that the detected cluster anions observed in this study must be formed by a two-step process: first, laser ablation forms $\left[\mathrm{TiO}_{2}\right]_{\mathrm{x}}{ }^{-}$, and secondly, a reaction in the gas phase with water and dioxygen molecules occurs. The reaction with water must be described as a hydrolysis mechanism of some titanium-oxygen bonds in 
Table 1. Fragmentation pattern of $\left[\left(\mathrm{TiO}_{2}\right)_{3}\left(\mathrm{H}_{2} \mathrm{O}\right)_{0-1} \mathrm{OH}\right]^{-}$and $\left[\left(\mathrm{TiO}_{2}\right)_{3}\left(\mathrm{H}_{2} \mathrm{O}\right) \mathrm{O}_{2}\right]^{-}$cluster ion with respect to the energy per cycle in the center of mass frame in SORI-CID mode

\begin{tabular}{|c|c|c|c|c|c|c|c|}
\hline Parent ion & $m / z$ & $\mathrm{E}_{\mathrm{COM}}(\mathrm{eV})$ & & & ment ions & & \\
\hline \multirow{7}{*}{$\left(\mathrm{TiO}_{2}\right)_{3}\left(\mathrm{H}_{2} \mathrm{O}\right) \mathrm{OH}^{-}$} & & & $\left(\mathrm{TiO}_{2}\right)_{3}\left(\mathrm{H}_{2} \mathrm{O}\right) \mathrm{OH}^{-}$ & $\left(\mathrm{TiO}_{2}\right)_{3} \mathrm{OH}^{-}$ & $\left(\mathrm{TiO}_{2}\right)_{3}{ }^{-\bullet}$ & $\left(\mathrm{TiO}_{2}\right)_{2} \mathrm{OH}^{-}$ & $\left(\mathrm{TiO}_{2}\right) \mathrm{OH}$ \\
\hline & 274.8272 & 0.13 & 32 & 100 & - & - & - \\
\hline & & 0.19 & 18 & 100 & - & - & - \\
\hline & & 0.33 & 4 & 100 & 5 & - & - \\
\hline & & 0.42 & - & 100 & 8 & - & - \\
\hline & & 0.52 & 4 & 100 & 8 & 5 & 2 \\
\hline & & 0.74 & - & 100 & 24 & 12 & 3 \\
\hline \multirow[t]{3}{*}{$\left(\mathrm{TiO}_{2}\right)_{3} \mathrm{OH}^{-}$} & 256.8166 & 0.69 & - & - & 100 & - & - \\
\hline & & 0.75 & - & - & 100 & 39 & - \\
\hline & & & $\left(\mathrm{TiO}_{2}\right)_{2}\left(\mathrm{H}_{2} \mathrm{O}\right) \mathrm{O}_{2}^{-\bullet}$ & $\left(\mathrm{TiO}_{2}\right)_{3} \mathrm{O}_{2}^{-\cdot}$ & $\left(\mathrm{TiO}_{2}\right)_{3} \cdot$ & & \\
\hline \multirow[t]{2}{*}{$\left(\mathrm{TiO}_{2}\right)_{3}\left(\mathrm{H}_{2} \mathrm{O}\right) \mathrm{O}_{2} \cdot$} & 289.8143 & 0.23 & - & 100 & - & & \\
\hline & & 0.31 & - & 100 & 31 & & \\
\hline
\end{tabular}

the $\left[\mathrm{TiO}_{2}\right]_{\mathrm{x}}{ }^{-\bullet}$ cluster anions. In this respect, an alternative formalism may be used to account for the different anions observed in the mass spectrum with a "structural" connotation. This was previously proposed by Aubriet et al. for oxohydroxide cerium cluster anions [25]. Consequently, $\left[\left(\mathrm{TiO}_{2}\right)_{\mathrm{x}}\left(\mathrm{H}_{2} \mathrm{O}\right)_{\mathrm{y}} \mathrm{OH}\right]^{-}$must be seen as $\left[\mathrm{Ti}_{\mathrm{x}} \mathrm{O}_{2 \mathrm{x}-\mathrm{y}}(\mathrm{OH})_{2 \mathrm{y}+1}\right]^{-}$ and, $\left[\left(\mathrm{TiO}_{2}\right)_{\mathrm{x}}\left(\mathrm{H}_{2} \mathrm{O}\right)_{\mathrm{y}} \mathrm{O}_{2}\right]^{-\bullet}$ as $\left[\mathrm{Ti}_{\mathrm{x}} \mathrm{O}_{2 \mathrm{x}-\mathrm{y}}(\mathrm{OH})_{2 \mathrm{y}} \mathrm{O}_{2}\right]^{-\bullet}$ species. Such structures are supported by the results of DFT calculations, which are reported in the final section.

To support the hypothesis of a two-step mechanism for cluster ion formation, an additional MS/MS experiment was performed. After transfer in the FTICR MS cell, the ions were excited in an orbit, which is close to the detection plates. After $10 \mathrm{~s}$, the ions were excited for detection. In this experiment, the first excitation provides significant kinetic energy to the ions. During the 10-s delay, collisions between the ions and neutrals occurred, which ensured both fragmentation and thermalization. It was thought that the orbits of all the ions after $10 \mathrm{~s}$ were close to the center of the FTICR MS. The resulting mass spectrum is reported in Figure 3. It should be considered as similar to the full MS/MS spectrum of ions reported in Figure 1. Different cluster ions were observed. The associated $\mathrm{TiO}_{2} \mathrm{BB}$ and $\mathrm{OH}^{-}, \mathrm{OK}^{-}$, and $\mathrm{O}_{2}^{-\bullet} \mathrm{CC}$ $\left[\mathrm{TiO}_{2}\right]_{\mathrm{x}}^{-\bullet}$ anions were also detected. With the exception of $\mathrm{O}_{2}{ }^{-\bullet}$-containing $\mathrm{CC}$ species, all of these anions were detected in previous studies [32]. Large superoxide-type cluster anions were thought to be stable enough to survive fragmentation after the first excitation event. To confirm the two-step mechanism, ion-molecule reactions were conducted between $\left[\mathrm{TiO}_{2}\right]_{\mathrm{x}}{ }^{-\bullet}$ and water or $\mathrm{O}_{2}$ molecules.

\section{Reaction in the Gas Phase}

The reaction between $\left[\mathrm{TiO}_{2}\right]_{3,6-12}{ }^{-\bullet}$ cluster ions and water or dioxygen in the FTICR MS cell was systematically investigated. Supplementary materials clearly demonstrate the ability of the MS/MS experiments performed on $\left[\left(\mathrm{TiO}_{2}\right)_{\mathrm{x}}(-\right.$ $\left.\left.\mathrm{H}_{2} \mathrm{O}\right)_{\mathrm{y}} \mathrm{OH}\right]^{-}$and/or $\left[\left(\mathrm{TiO}_{2}\right)_{\mathrm{x}}\left(\mathrm{H}_{2} \mathrm{O}\right)_{\mathrm{y}} \mathrm{O}_{2}\right]^{-\bullet}$ to efficiently yield $\left[\left(\mathrm{TiO}_{2}\right)_{\mathrm{x}}\right]^{-\bullet}$ anions. After formation and selection, the ions of interest were trapped at the center of the FTICR MS cell by means of the combination of electric and magnetic fields. The reaction of these ions with $\mathrm{H}_{2} \mathrm{O}$ and $\mathrm{O}_{2}$ was investigated under two different experimental conditions. The first one required the introduction into the ICR cell of $\mathrm{N}_{2}$, which

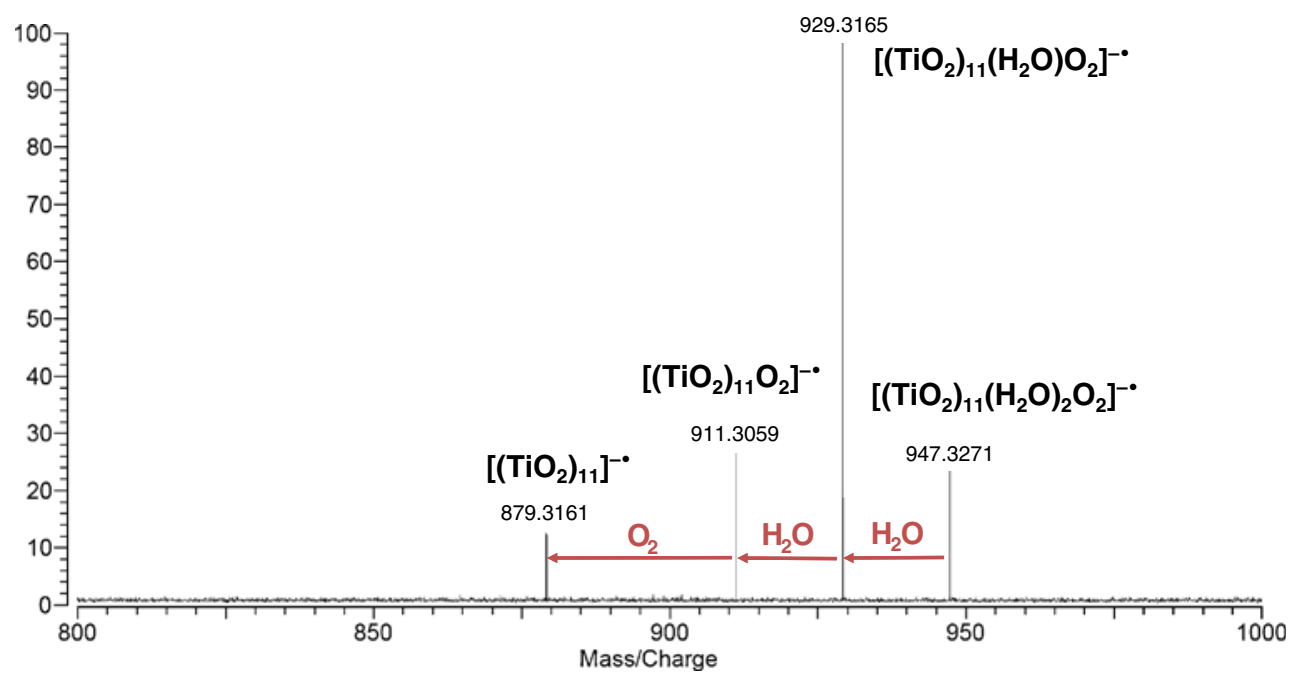

Figure 2. SORI-CID tandem mass spectrometry measurement of $\left[\left(\mathrm{TiO}_{2}\right)_{11}\left(\mathrm{H}_{2} \mathrm{O}\right)_{3} \mathrm{O}_{2}\right]^{-\bullet}$ at $m / z 947.327$ with an $\mathrm{E}_{\mathrm{COM}}$ of $0.08 \mathrm{eV}$ per cycle 


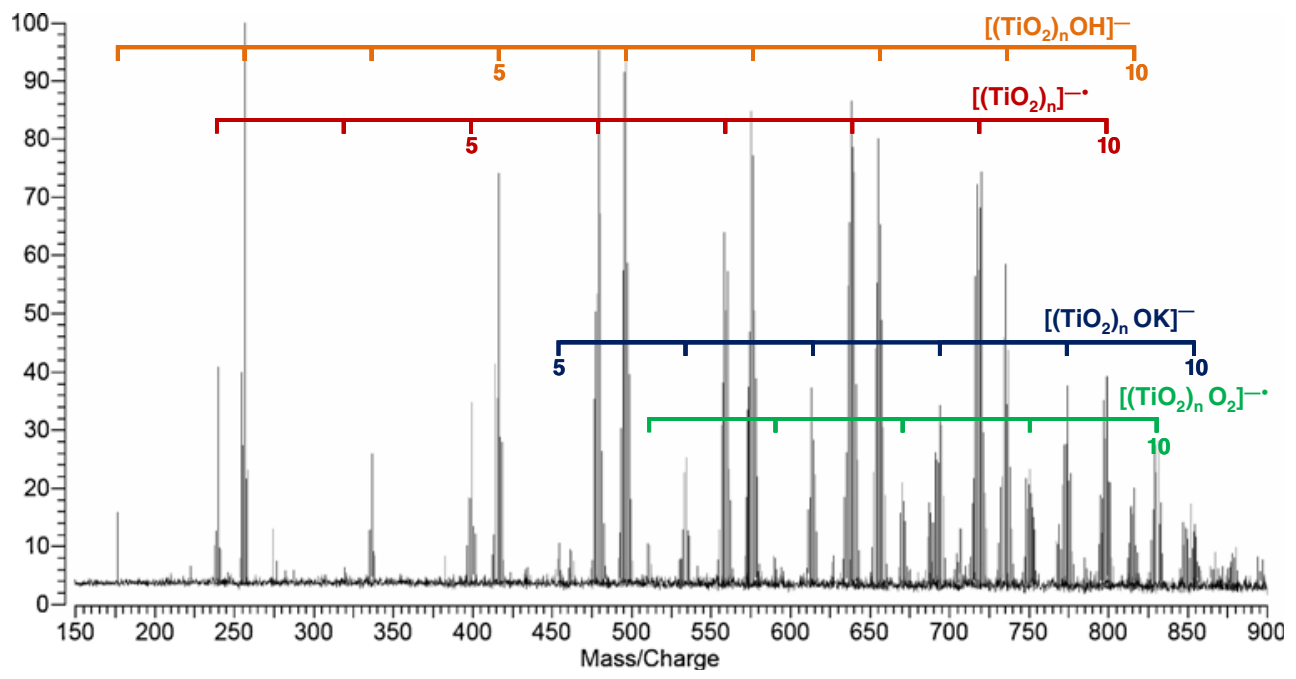

Figure 3. Negative ion mass spectrum of $\mathrm{TiO}_{2}$ obtained by LA-FTICR MS after a double excitation before detection

acted as buffer gas with small amounts of $\mathrm{H}_{2} \mathrm{O}$ and $\mathrm{O}_{2}$. This allowed the nature of the produced species to be identified. A second type of experiment was conducted to study the kinetics of the reaction between $\left[\mathrm{TiO}_{2}\right]_{3-11}{ }^{-\bullet}$ and water. In that case, no gas was added to the ICR cell to be sure that the reactions were conducted at a static pressure, allowing the kinetic constant to be extracted from experimental results. Residual pressure was thought, as previously reported by Aubriet et al. [25], to be mainly associated with water vapor. In the latter case, the anion distribution was studied depending on the reaction time.

Figure 4 reports the results obtained after the reaction of $\left[\left(\mathrm{TiO}_{2}\right)_{3}\right]^{-\bullet}$ anions with water and the dioxygen molecule in the gas phase for both experimental conditions. After $2 \mathrm{~s}$ at a pressure of $5 \times 10^{-10}$ Torr (Figure 4a), a new anion was observed at $\mathrm{m} / \mathrm{z}$ 257.8242, which corresponds to $\left[\left(\mathrm{TiO}_{2}\right)_{3}\left(\mathrm{H}_{2} \mathrm{O}\right)\right]^{-\bullet}$. The relative abundance of this ion significantly increased when longer reaction times were considered. After $20 \mathrm{~s}$, a large part of the $\left[\left(\mathrm{TiO}_{2}\right)_{3}\right]^{-\bullet}$ anions had reacted and accommodated a water molecule. It is also important to note that another signal was detected on the mass spectrum reported in Figure $4 \mathrm{~b}$ at $m / z 256.8164$ that did not correspond to the isotopic pattern of $\left[\left(\mathrm{TiO}_{2}\right)_{3}\left(\mathrm{H}_{2} \mathrm{O}\right)\right]^{-\cdot}$, but instead to the $\left[\left(\mathrm{TiO}_{2}\right)_{3} \mathrm{OH}\right]^{-}$anion. The mass resolution and the mass measurement accuracy obtained with the experimental conditions were sufficient enough to distinguish both possible assignments. This clearly highlighted the occurrence of a second reaction pathway and the general trend of titanium to be tetravalent in the gas phase. The introduction of nitrogen with small amounts of water and dioxygen for a 50-ms period of time into the FTICR MS cell showed evidence of other reaction pathways and the increase in the energy of ion-molecule reactions. Indeed, the pressure after the opening of the pulsed valve increased temporarily by two orders of magnitude, which has a direct effect on the efficiency of ion-molecule reactions by increasing the collision rate and the thermalization of resulting species. As a consequence, the intensity of $\left[\left(\mathrm{TiO}_{2}\right)_{3}\right]^{-\bullet}$ anion dramatically decreased, and both the number and the abundance of resulting ions increased. In addition to ions observed in Figure $4 \mathrm{~b}$, ions at higher $\mathrm{m} / \mathrm{z}$ ratio were detected at $\mathrm{m} / \mathrm{z}$ $271.8036,274.8271,275.8349$, and 289.8142, which were assigned to $\left.\left[\left(\mathrm{TiO}_{2}\right)_{3} \mathrm{O}_{2}\right)\right]^{-},\left[\left(\mathrm{TiO}_{2}\right)_{3}\left(\mathrm{H}_{2} \mathrm{O}\right) \mathrm{OH}\right]^{-}$, $\left[\left(\mathrm{TiO}_{2}\right)_{3}\left(\mathrm{H}_{2} \mathrm{O}\right)_{2}\right]^{-*}$, and $\left.\left[\left(\mathrm{TiO}_{2}\right)_{3}\left(\mathrm{H}_{2} \mathrm{O}\right) \mathrm{O}_{2}\right)\right]^{-\bullet}$, respectively. Except $\left[\left(\mathrm{TiO}_{2}\right)_{3}\left(\mathrm{H}_{2} \mathrm{O}\right)_{1} \text { and } 2\right]^{\bullet}$ anions, all species resulting from ion-molecule reactions between $\left[\left(\mathrm{TiO}_{2}\right)_{3}\right]^{-\bullet}$ and water and or dioxygen have been observed on the negative mass spectra (Figure 1). The same types of reactions were still highlighted in the study of other ion-molecule reactions with water and dioxygen [26, 35, 36]. Reactive ions were mainly oxygenated anions of chromium, alumina, silicon or cerium. The significant energy required to ensure both the elimination of added water or dioxygen molecules by MS/MS experiments (see previous section and supplementary materials) is consistent with the formation of bonds and not with weak bonding interactions between water or the dioxygen molecule and the investigated ion. As a consequence, the reaction of $\left[\left(\mathrm{TiO}_{2}\right)_{3}\right]^{-}$with water can be clearly seen as a hydrolysis process, whereas the reaction with dioxygen is described as the oxidation of one titanium atom (the trivalent one) to form peroxo-anions. The investigation of the charge distribution and the spin density for some specific species by quantum chemistry, which are presented in last section, supports all these assessments. The reaction of $\left[\left(\mathrm{TiO}_{2}\right)_{3}\right]^{-}$with water or dioxygen may be competitive and/or successive processes. For example, the hydrolysis of the titanium oxygen bond to form $\left[\left(\mathrm{TiO}_{2}\right)_{3}\left(\mathrm{H}_{2} \mathrm{O}\right)\right]^{-\bullet}$ is competitive to the formation of the $\left.\left[\left(\mathrm{TiO}_{2}\right)_{3} \mathrm{O}_{2}\right)\right]^{*}$ ion and may be followed by the reaction with water or dioxygen to form either $\left[\left(\mathrm{TiO}_{2}\right)_{3}\left(\mathrm{H}_{2} \mathrm{O}\right)_{2}\right]^{-\bullet}$ or $\left.\left[\left(\mathrm{TiO}_{2}\right)_{3}\left(\mathrm{H}_{2} \mathrm{O}\right) \mathrm{O}_{2}\right)\right]^{-\bullet}$ species, respectively. It has to be noticed that $\left[\left(\mathrm{TiO}_{2}\right)_{3}\right]^{-\bullet}$ and more generally $\left[\left(\mathrm{TiO}_{2}\right)_{\mathrm{x}}\right]^{-\bullet}$ never accommodated more than one dioxygen molecule, but may successively react with three water molecules. The formation of $\left[\left(\mathrm{TiO}_{2}\right)_{3} \mathrm{OH}\right]^{-}$is more questionable. Indeed, different 

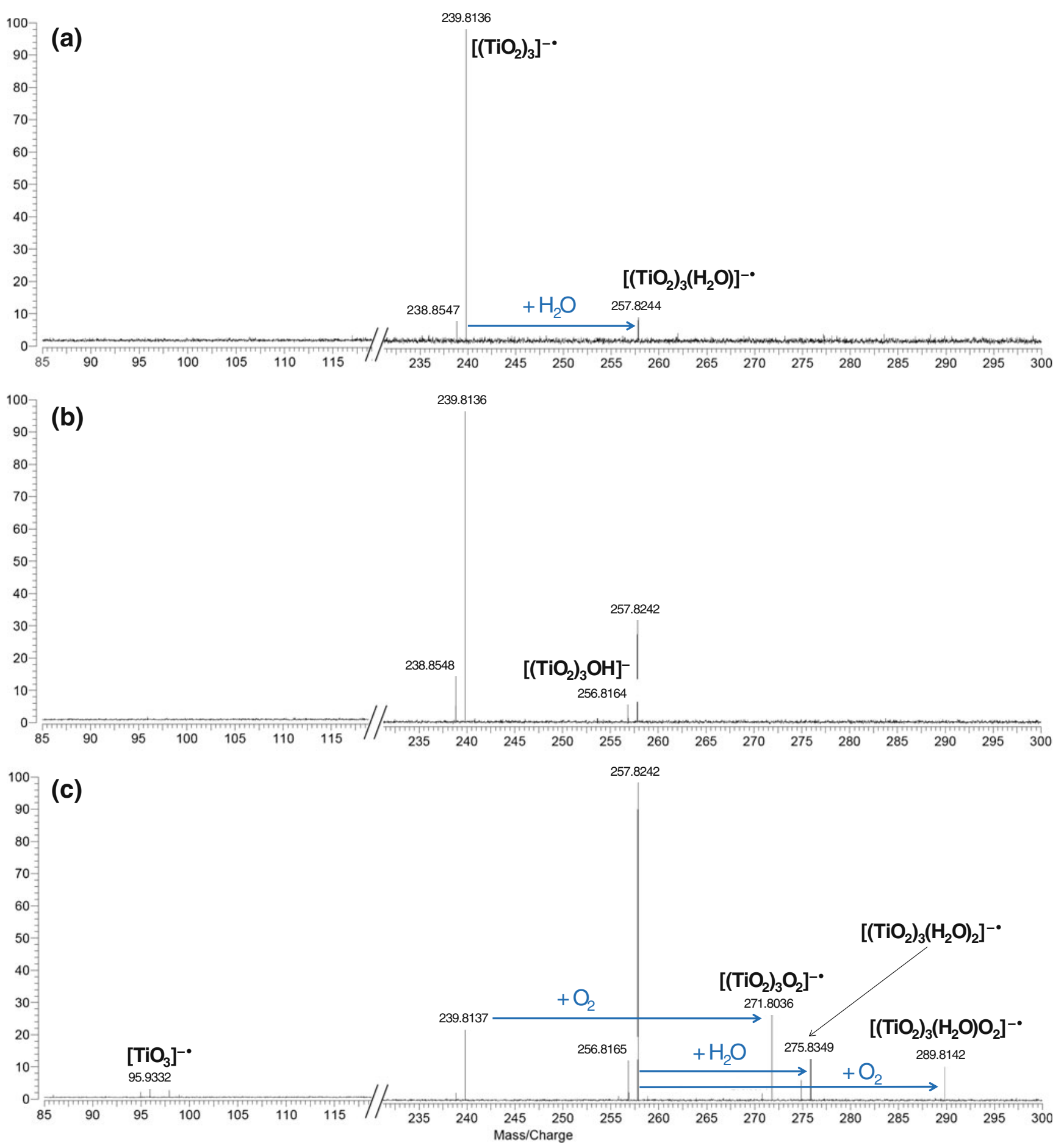

Figure 4. Mass spectra observed after SORI-CID of $\left[\left(\mathrm{TiO}_{2}\right)_{3}\left(\mathrm{H}_{2} \mathrm{O}\right) \mathrm{OH}\right]-$ at $\mathrm{m} / \mathrm{z} 274.8272$ and SWIFT isolation to yield the $\left(\mathrm{TiO}_{2}\right)_{3}{ }^{-}$ ion at $\mathrm{m} / \mathrm{z} 239.8138$ and reaction with residual $\mathrm{H}_{2} \mathrm{O}$ at a pressure of $2 \times 10^{-10}$ Torr after (a) a 2-s reaction time, (b) a 20-s reaction time, and (c) reaction with $\mathrm{H}_{2} \mathrm{O}$ and/or $\mathrm{O}_{2}$ after a 20-s reaction time and introduction for 50-ms of a pulse of nitrogen with small amounts of $\mathrm{H}_{2} \mathrm{O}$ and $\mathrm{O}_{2} ; \mathrm{m} / \mathrm{z} 238.8548$ anion is associated to the isotopic pattern of $\left(\mathrm{TiO}_{2}\right)_{3}{ }^{\bullet}$ cluster anion

processes have to be considered to explain the formation of non-radical species by radical ion reactions with a molecule. The driving force is the formation of a cluster ion with all titanium atoms in the tetravalent oxidation state. The first process has to be considered as an alternative to the formation of $\left[\left(\mathrm{TiO}_{2}\right)_{3}\left(\mathrm{H}_{2} \mathrm{O}\right)\right]^{-\bullet}$, in which a hydrogen atom was elimi- nated during the formation of the hydroxide bond. The second process may be associated with $\left[\left(\mathrm{TiO}_{2}\right)_{3}\left(\mathrm{H}_{2} \mathrm{O}\right)\right]^{-}$in the ground or excited state, which is stabilized by the elimination of a hydrogen atom and the concomitant oxidation of titanium into the tetravalent state. This recombination may be assisted by the interaction of $\left[\left(\mathrm{TiO}_{2}\right)_{3}\left(\mathrm{H}_{2} \mathrm{O}\right)\right]^{-}$with one dioxygen 
molecule and the formation of the well known $\mathrm{HOO}^{\circ}$ hydroperoxy radical. The addition of one water molecule may then occur, as was demonstrated in Figure 5. Nevertheless, the reactivity of these non-radical species is less than that of the $\left[\left(\mathrm{TiO}_{2}\right)_{3}\right]^{\bullet}$ radical anion. Nevertheless, it may be argued that $\left[\left(\mathrm{TiO}_{2}\right)_{3}\left(\mathrm{H}_{2} \mathrm{O}\right) \mathrm{OH}\right]^{-}$was mainly formed from $\left[\left(\mathrm{TiO}_{2}\right)_{3} \mathrm{OH}\right]^{-}$by the hydrolysis process according to the results reported in Figure 5 even if the reaction kinetics are slower. Generally, the reaction of $\left[\left(\mathrm{TiO}_{2}\right)_{\mathrm{n}}\right]^{-}$with the first, second and third water molecule is fast at a pressure of $2 \times 10^{-10}$ Torr; however, it may be consequently considered as quasi-spontaneous in the storage hexapole at a $10^{6}$ higher pressure. The successive addition of water and dioxygen molecules appeared to decrease the efficiency of the ionmolecule reactions. Indeed, the addition of water and oxygen molecules was found to be limited to 3 and 1, respectively. Finally, an intriguing ion was also detected at $\mathrm{m} / \mathrm{z} 95.9332$ corresponding to $\left[\mathrm{TiO}_{3}\right]^{-}$. This ion had to be generated by a reactive, dissociative event. The formation of bonds between atoms from water or dioxygen and atoms of the cluster ions induced the electron depletion of bonds (and ultimately their dissociation) into the cluster anion. Part of the produced ion may consequently be associated with smaller species if too many internal cluster ion bonds were broken. This may also be a reasonable explanation to the restricted number of added water or dioxygen molecules.

\section{Structure, Energy, and Spin Density of Oxy-Hydroxide Titanium Cluster Anions}

The structure and the energy associated with the different cluster ion conformers, including three titanium atoms and an odd or an even number of hydroxide groups, were reported in Figure 6 when calculated with the $6-311+\mathrm{G}(2 \mathrm{~d}$, p) basis. Results for the LanL2DZ basis are displayed in Supplementary Information 4. Some structures for cluster anions with a peroxy group are given in Supplementary Information 5. Supplementary Information 6 gives DFT details (structures, cartesian coordinates, etc.) for all the calculated structures. Generally, structures obtained with both bases are very close, but the energies are significantly different due to the diffuse and polarization effects introduced by the $6-311+\mathrm{G}(2 \mathrm{~d}, \mathrm{p})$ basis. Two structures were found to be stable for $\left[\left(\mathrm{TiO}_{2}\right)_{3}\right]^{-\bullet}$ cluster anions. The more stable is the Cs structure, whereas the $\mathrm{C}_{2 \mathrm{v}}$ structure was calculated to be $29.4 \mathrm{kcal} / \mathrm{mol}$ higher in energy. The structure and the relative stability were confirmed with that previously found by Albaret et al. [37].

The addition of a water or oxygen molecule, which was experimentally observed, led to the systematic decrease of the energy. This process is consequently thermodynamically favored. The energy values reported in Figure 6 are relative to the difference in energy between the reactant and the product. The successive reactions with water molecules led to a progressive loss of symmetry and the opening of 4membered rings. The reaction of $\left[\mathrm{Ti}_{3} \mathrm{O}_{4}(\mathrm{OH})_{4}\right]^{-\bullet}$ or $\left[\mathrm{Ti}_{3} \mathrm{O}_{5}(\mathrm{OH})_{3}\right]^{-}$cluster anions with a third water molecule or $\mathrm{O}_{2}$ was thought to induce the dissociation of additional bonds and the formation of a dangling titanium hydroxide group. It may be assumed that pending parts of the ion may be easily released by collisions in the gas phase, which induced the formation of species with one or two titanium atoms. This is supported by the non-detection of $\left[\mathrm{Ti}_{3} \mathrm{O}_{3}(\mathrm{OH})_{6}\right]^{-\cdot}$, $\left[\mathrm{Ti}_{3} \mathrm{O}_{4}(\mathrm{OH})_{4} \mathrm{O}_{2}\right]^{-\bullet},\left[\mathrm{Ti}_{3} \mathrm{O}_{4}(\mathrm{OH})_{5}\right]^{-}$, and $\left[\mathrm{Ti}_{3} \mathrm{O}_{5}(\mathrm{OH})_{3} \mathrm{O}_{2}\right]^{-}$ anions on the different mass spectra reported in this study and the detection of $\left[\mathrm{TiO}_{3}\right]^{-}$on the mass spectrum reported in Figure $4 \mathrm{c}$. The formation of this anion, which remains under discussion, may be associated with successive dissociation events after the reaction of $\left[\mathrm{Ti}_{3} \mathrm{O}_{4}(\mathrm{OH})_{4}\right]^{\bullet}$ with water or dioxygen. The first event may be elimination after the reaction of the dangling group followed by the elimination of the water molecule via hydroxide condensation.

The addition of a water molecule on $\left[\left(\mathrm{TiO}_{2}\right)_{3}\right]^{\bullet}$ led to the formation of $\left[\mathrm{Ti}_{3} \mathrm{O}_{5}(\mathrm{OH})_{2}\right]^{-\bullet}$ by a hydration process. All the calculated structures have energy lower than the sum of the water and $\mathrm{Cs}\left[\left(\mathrm{TiO}_{2}\right)_{3}\right]^{\bullet}$ energy. Moreover, the lowest energy $\left[\mathrm{Ti}_{3} \mathrm{O}_{4}(\mathrm{OH})_{4}\right]^{-}$structure is $31.3 \mathrm{kcal} / \mathrm{mol}$ higher in energy than the sum of the energy of water with the $\left[\mathrm{Ti}_{3} \mathrm{O}_{5}(\mathrm{OH})_{2}\right]^{-}$
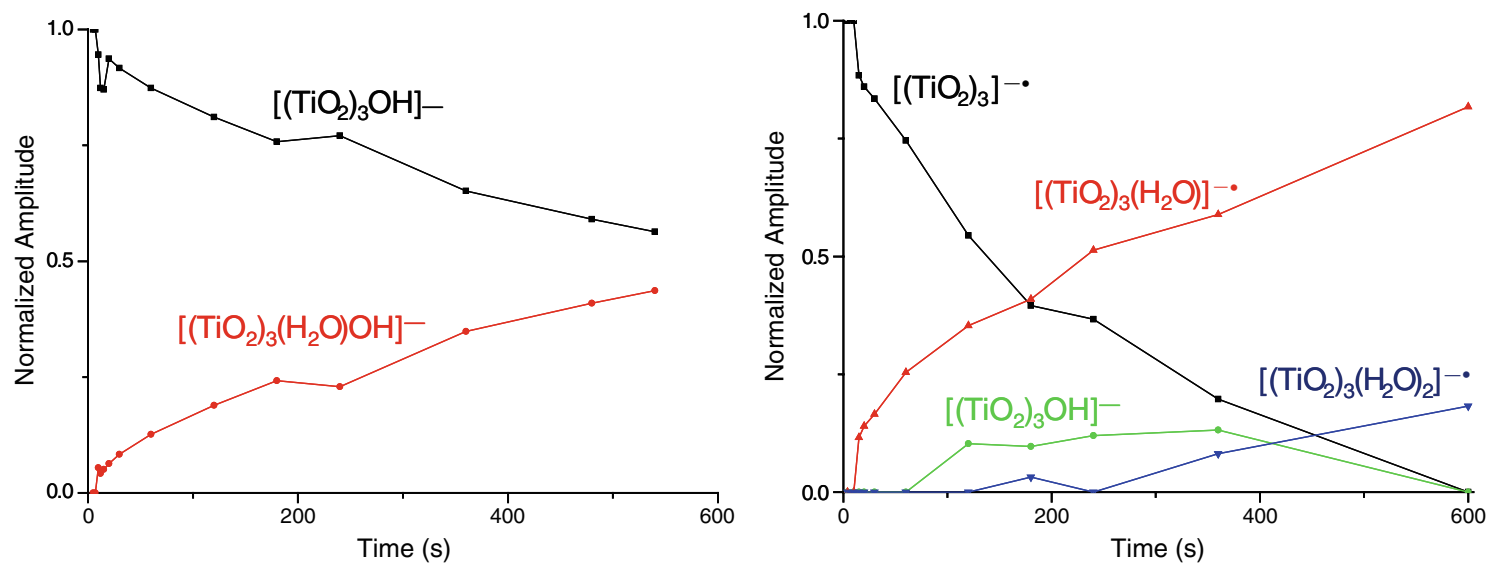

Figure 5. Kinetic study of the ion-molecule reaction of (left) $\left[\left(\mathrm{TiO}_{2}\right)_{3} \mathrm{OH}\right]^{-}$and (right) $\left[\left(\mathrm{TiO}_{2}\right)_{3}\right]^{-\bullet}$ with water and/or dioxygen, for which the kinetic constant of reactive ion disappearance was $\mathrm{k}_{\mathrm{d}}=8 \times 10^{-4} \mathrm{~s}^{-1}$ and $2 \times 10^{-3} \mathrm{~s}^{-1}$, respectively 


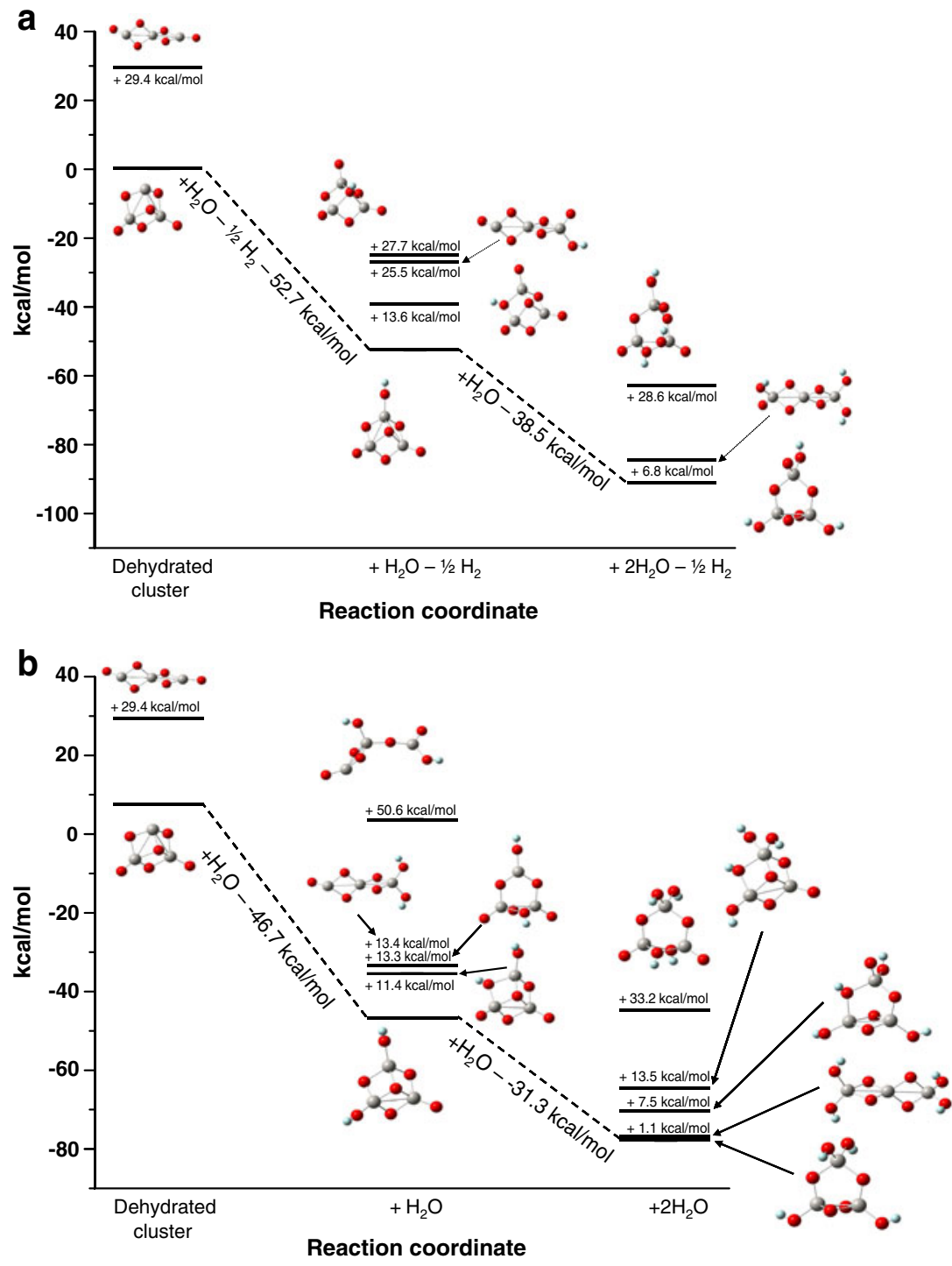

Figure 6. Reaction coordinate diagram and structures of reactants and products calculated for species with three titanium atoms undergoing hydration with the 6-311+ $\mathrm{G}\left(2 \mathrm{~d}\right.$,p) basis: for (a) $\left[\left(\mathrm{TiO}_{2}\right)_{3}\right]^{-\bullet}+\mathrm{H}_{2} \mathrm{O} \rightarrow\left[\mathrm{Ti}_{3} \mathrm{O}_{6}(\mathrm{OH})\right]^{-}+1 / 2 \mathrm{H}_{2}$ and $\left[\mathrm{Ti}_{3} \mathrm{O}_{6}(\mathrm{OH})\right]^{-}+$ $\mathrm{H}_{2} \mathrm{O} \rightarrow\left[\mathrm{Ti}_{3} \mathrm{O}_{5}(\mathrm{OH})_{3}\right]^{-}$and (b) $\left[\left(\mathrm{TiO}_{2}\right)_{3}\right]^{\bullet}+\mathrm{H}_{2} \mathrm{O} \rightarrow\left[\mathrm{Ti}_{3} \mathrm{O}_{5}(\mathrm{OH})_{2}\right]^{-\bullet}$ and $\left[\mathrm{Ti}_{3} \mathrm{O}_{5}(\mathrm{OH})_{2}\right]^{-\bullet}+\mathrm{H}_{2} \mathrm{O} \rightarrow\left[\mathrm{Ti}_{3} \mathrm{O}_{4}(\mathrm{OH})_{4}\right]^{-\bullet}$ processes

structure, which seems to indicate that the hydration is also thermodynamically favored. It is also thought that different conformers for each $\left[\mathrm{Ti}_{3} \mathrm{O}_{\mathrm{x}}(\mathrm{OH})_{\mathrm{y}}\right]^{-}$and $\left[\mathrm{Ti}_{3} \mathrm{O}_{\mathrm{x}},(\mathrm{OH})_{\mathrm{y}}\right]^{-}$ions are simultaneously present, especially when the difference in energy is very close. The energy of the different $\left[\mathrm{Ti}_{3} \mathrm{O}_{5}(\mathrm{OH})_{3}\right]^{-}$ calculated structures was found to be very close, i.e., $6.8 \mathrm{kcal} /$ mol (see in Figure 6b). It is then reasonable to consider that different $\left[\mathrm{Ti}_{3} \mathrm{O}_{5}(\mathrm{OH})_{3}\right]^{-}$isomers, especially the "Cs-like" and the " $\mathrm{C}_{2 \mathrm{v}}$-like" species, were simultaneously present in the FTICR MS cell. The significant structural differences between "Cs-like" and the " $\mathrm{C}_{2 \mathrm{v}}$-like" seems to indicate that the formation by $\mathrm{MS} / \mathrm{MS}$ of $\mathrm{Cs}$ or $\mathrm{C}_{2 \mathrm{v}}\left[\left(\mathrm{TiO}_{2}\right)_{3}\right]^{-}$from " $\mathrm{C}_{2 \mathrm{v}}$-like" or "Cs-like", respectively, is highly disfavored according to the low activation energy used in SORI experiments. Consequently, both $\mathrm{Cs}$ and $\mathrm{C}_{2 \mathrm{v}}\left[\left(\mathrm{TiO}_{2}\right)_{3}\right]^{-}$are present in the FTICR MS cell after MS/MS experiments and may undergo successive hydration processes, especially the $\mathrm{C}_{2 \mathrm{v}}$ structure.
Before the MS/MS experiment in the FTICR MS cell, $\left[\mathrm{Ti}_{3} \mathrm{O}_{5}(\mathrm{OH})_{3}\right]^{-}$anions have to be generated in the ion source by the two-step process proposed in previous sections. Arguments developed in the previous paragraph on the difficulties for the lowest energy $\left[\mathrm{Ti}_{3} \mathrm{O}_{5}(\mathrm{OH})_{2}\right]^{-\bullet}$ structure to easily accommodate an additional water molecule should be considered when $\left[\left(\mathrm{TiO}_{2}\right)_{3}\right]^{\bullet}$ anions generated by laser ablation react with water molecules in the external ion source. In that case, the internal energy distribution of anions is broader, and higher energy conformers may be formed due to the laser matter interaction event and the relative inefficiency of thermalization during the first step of the emission of species from the surface. Consequently, different structures for a given ion may be present in the gas phase, especially those reported in Figure 6.

Calculations performed for the $\left[\left(\mathrm{TiO}_{2}\right)_{3} \mathrm{O}_{2}\right]^{-\bullet}$ anion clearly indicated that the more stable structures are associ- 
ated with species of a peroxo or an end-on superoxo group and not the tetrakis-oxo structure. Moreover, the formation of the tetrakis-oxo structure was thought to be highly disfavored according to the distance between each terminal titanium atom in the $\mathrm{C}_{2 \mathrm{v}}\left[\left(\mathrm{TiO}_{2}\right)_{3}\right]^{-}$anion and the distribution of the Mulliken spin density, given in Supplementary Information 6 , for $\mathrm{C}_{2 \mathrm{v}}\left[\left(\mathrm{TiO}_{2}\right)_{3}\right]^{-\bullet}$ anion. In a molecule or an ion, atoms with a high Mulliken spin density are generally considered to be more reactive. Consequently, the addition of dioxygen to the $\mathrm{Cs}$ or $\mathrm{C}_{2 \mathrm{v}}\left[\left(\mathrm{TiO}_{2}\right)_{3}\right]^{-}$anion and the formation of $\left[\left(\mathrm{TiO}_{2}\right)_{3} \mathrm{O}_{2}\right]^{\bullet}$ may be well explained for four of the five calculated structures given in Supplementary Information 6 , but not for the $\mathrm{C}_{2 \mathrm{v}}$-tetrakis-oxo structure due to the lack of simultaneous high Mulliken spin density on both terminal titanium atoms.

Mulliken spin density was also calculated for the lowest energy structures of $\left[\mathrm{Ti}_{3} \mathrm{O}_{5}(\mathrm{OH})_{2}\right]^{-\bullet},\left[\mathrm{Ti}_{3} \mathrm{O}_{4}(\mathrm{OH})_{4}\right]^{-\bullet}$, $\left[\mathrm{Ti}_{3} \mathrm{O}_{6}\left(\mathrm{O}_{2}\right)\right]^{\bullet}$, and $\left[\mathrm{Ti}_{3} \mathrm{O}_{5}(\mathrm{OH})_{2}\left(\mathrm{O}_{2}\right)\right]^{\bullet}$ anions (see Supplementary Information 7) and also for the Cs or $\mathrm{C}_{2 \mathrm{v}}\left[\left(\mathrm{TiO}_{2}\right)_{3}\right]^{-}$ species. Significant charge Mulliken density was systematically observed, which supports the radical behavior previously considered for each of these species. It is of significant interest to note that systematically, the highest spin density was associated with a titanium atom, which may also support the presence of a titanium-reduced center. The Mulliken spin density for $\left[\mathrm{Ti}_{3} \mathrm{O}_{6}(\mathrm{OH})\right]^{-}$and $\left[\mathrm{Ti}_{3} \mathrm{O}_{5}(\mathrm{OH})_{3}\right]^{-}$was evidently found to be equal to zero for each atom of the cluster anion. This difference in unpaired electron population for $\left[\left(\mathrm{TiO}_{2}\right)_{3}\right]^{-}$on the one hand and for $\left[\mathrm{Ti}_{3} \mathrm{O}_{6}(\mathrm{OH})\right]^{-}$on the other hand may be useful to explain the difference in kinetic rates observed when these ions react in the gas phase with $\mathrm{H}_{2} \mathrm{O}$, as is reported in Fig. 5 .

The Mulliken charges on the different titanium atoms for Cs or $\mathrm{C}_{2 \mathrm{v}}\left[\left(\mathrm{TiO}_{2}\right)_{3}\right]^{-\bullet}$ species and for the different anions produced by their reaction with water or oxygen may be of significant interest. Indeed, these charges may be useful to evaluate the ability of the reduced titanium center to be oxidized in the gas phase by reaction with water and dioxygen. The Mulliken charge obtained for titanium atoms by considering $\mathrm{TiO}, \mathrm{Ti}_{2} \mathrm{O}_{3}$, and $\mathrm{TiO}_{2}$ neutrals in the gas phase were $0.433,0.888$, and 0.912 , respectively. These charges correspond to the difference between the atomic number of titanium, i.e., 22, and the calculated electron density of the titanium atom in the considered cluster. For the $\mathrm{C}_{2 \mathrm{v}}\left[\left(\mathrm{TiO}_{2}\right)_{3}\right]^{-}$, the charge of the three titanium atoms was found to be $0.827,1.129$, and 1.011 from the right to the left $\mathrm{Ti}$ ( $\mathrm{Ti}$ atoms label 7, 1, and 6, respectively, in Supplementary Information 6) of the structure reported in Figure 6. For the Cs structure, the two equivalent bottom titanium atoms have a 1.091 Mulliken charge, whereas the top one has a charge of 0.990 . Consequently, titanium atoms adopt different oxidation states, at least one of which appears to be a reduced titanium oxidation state. The reaction of each of atom with water or oxygen induced an increase of the positive Mulliken charge for each titanium atom, especially for the reduced titanium center in the range from 1.155 to 1.274 for "Cs-like" $\left[\mathrm{Ti}_{3} \mathrm{O}_{6}(\mathrm{OH})\right]^{-}$structures and 1.086 for the " $\mathrm{C}_{2 \mathrm{v}}$ like" $\left[\mathrm{Ti}_{3} \mathrm{O}_{6}(\mathrm{OH})\right]^{-}$structure. The reaction with an additional water molecule confirms this feature. These trends were also observed when $\left[\left(\mathrm{TiO}_{2}\right)_{3}\right]^{-}$reacts with dioxygen, the Mulliken charge of the initial reduced titanium center ranges from 1.019 to 1.272 , depending on the considered structure after the reaction.

\section{Conclusions}

The experimental and theoretical study of laser ablated titanium oxides by an external ion source FTICR MS allowed the investigation of a large number of cluster ions. The partial reaction with water and dioxygen was found to be associated with the oxidation of the reduced titanium center in the case of radical species in the gas phase. This is of significant importance to better understand processes occurring in the gas phase after the emission of species from the surface upon laser irradiation during reactive pulsed-laser deposition of ceramic materials, such as titanium oxides. Even if the main part of the species present in gas phase after laser-matter interaction is neutral, mass spectrometry results showing the ionized fraction of the laser plume may be tentatively transposed to neutral species. The increase in the titanium oxidation number after the reaction of reduced titanium species with water or dioxygen appeared to be a general trend.

The fine control of these processes, especially by considering the kinetics, must be implemented to ensure the deposition of $\mathrm{TiO}_{2}$ or substoichiometric $\mathrm{TiO}_{2}$. In this context, it was also found that water may significantly contribute to the oxidation of reduced titanium atoms. Both water and dioxygen should be finely controlled during a PLD experiment to adjust the desired stoichiometry of titanium in the obtained thin film.

\section{Acknowledgement}

The authors thank the French Ministère de l'Enseignement Supérieur et de la Recherche for funding. The authors also greatly appreciate the valuable discussions with Professor G. Groenewold, Professor X. Assfeld, and Professor J-J. Gaumet. Professor G. Groenewold and Professor J-J. Gaumet are also acknowledged for editing.

\section{References}

1. Andronic, L.; Duta, A. $\mathrm{TiO}_{2}$ thin films for dyes photodegradation. Thin. Solid. Films. 515, 6294-6297 (2007)

2. Brunella, M. F.; Diamanti, M. V.; Pedeferri, M. P.; Fonzo, F. D.; Casari, C. S.; Bassi, A. L. Photocatalytic behavior of different titanium dioxide layers. Thin. Solid. Films. 515, 6309-6313 (2007)

3. Diebold, U. The surface science of titanium dioxide. Surf. Sci. Rep. 48, 53-229 (2003)

4. Wang, T., Wang, H., Xu, P., Zhao, X., Liu, Y., Chao, S. The effect of properties of semiconductor oxide thin films on photocatalytic decomposition of dyeing waste water. Thin. Solid. Films. 334, 103-108 (1998)

5. Fujishima, A., Honda, K. Electrochemical photolysis of water at a semiconductor electrode. Nature 238, 37-38 (1972)

6. Hossein-Babaei, F., Keshmiri, M., Kakavand, M., Troczynski, T.: A resistive gas sensor based on undoped p-type anatase. Sens. Actuators B Chem.110, 28-35 (2005) 
7. Rella, R., Spadavecchia, J., Manera, M. G., Capone, S., Taurino, A., Martino, M., Caricato, A. P., Tunno, T. Acetone and ethanol solid-state gas sensors based on $\mathrm{TiO}_{2}$ nanoparticles thin film deposited by matrix assisted pulsed laser evaporation. Sens. Actuators B Chem. 127, 426431 (2007)

8. Earle, M. D. The electrical conductivity of titanium dioxide. Phys. Rev. 61, 56 (1942)

9. Haglund, R.F.: Microscopic and mesoscopic aspects of laser-induced desorption and ablation. Appl. Surf. Sci. 96/98, 1-13 (1996)

10. Girault, C., Damiani, D., Aubreton, J., Catherinot, A.: Time-resolved spectroscopic study of the $\mathrm{KrF}$ laser-induced plasma plume created above an $\mathrm{YBaCuO}$ superconducting target. Appl. Phys. Lett. 55, 182 184 (1989)

11. Otis, C.E., Dreyfus, R.W.: Laser ablation of $\mathrm{YBa}_{2} \mathrm{Cu}_{3} \mathrm{O}_{7-\delta}$ as probed by laser-induced fluorescence spectroscopy. Phys. Rev. Lett. 67, 2102 (1991)

12. Andrews, L., Chertihin, G.V., Ricca, A., Bauschlicher, C.W.: Reactions of laser-ablated iron atoms with oxygen molecules: matrix infrared spectra and density functional calculations of $\mathrm{OFeO}, \mathrm{FeOO}$, and $\mathrm{Fe}\left(\mathrm{O}_{2}\right)$. J. Am. Chem. Soc. 118, 467-470 (1996)

13. Chertihin, G.V., Andrews, L.: Reactions of laser-ablated manganese atoms with dioxygen. infrared spectra of $\mathrm{MnO}, \mathrm{OMnO}, \mathrm{Mn}\left(\mathrm{O}_{2}\right)$, $(\mathrm{MnO})_{2}$, and higher oxide complexes in solid argon. J. Phys. Chem. A 101, 8547-8553 (1997)

14. Chertihin, G.V., Andrews, L., Bauschlicher, C.W.: Reactions of laserablated copper atoms with dioxygen. Infrared spectra of the copper oxides $\mathrm{CuO}, \mathrm{OCuO}, \mathrm{CuOCuO}$, and $\mathrm{OCuOCuO}$ and superoxide $\mathrm{CuOO}$ in solid argon. J. Phys. Chem. A 101, 4026-4034 (1997)

15. Chertihin, G.V., Bare, W.D., Andrews, L.: Reactions of laser-ablated vanadium atoms with dioxygen. Infrared spectra of $\mathrm{VO}, \mathrm{VO}_{2}, \mathrm{OOVO}_{2}$, and $\mathrm{V}_{2} \mathrm{O}_{2}$ in solid argon. J. Phys. Chem. A 101, 5090-5096 (1997)

16. Chertihin, G.V., Citra, A., Andrews, L., Bauschlicher, C.W.: Reactions of laser-ablated cobalt atoms with $\mathrm{O}_{2}$. Infrared spectra of cobalt oxides in solid argon. J. Phys. Chem. A 101, 8793-8802 (1997)

17. Citra, A., Chertihin, G.V., Andrews, L., Neurock, M.: Reactions of laser-ablated nickel atoms with dioxygen. Infrared spectra and density functional calculations of nickel oxides $\mathrm{NiO}, \mathrm{ONiO}, \mathrm{Ni}_{2} \mathrm{O}_{2}$, and $\mathrm{Ni}_{2} \mathrm{O}_{3}$, superoxide $\mathrm{NiOO}$, peroxide $\mathrm{Ni}\left(\mathrm{O}_{2}\right)$, and higher complexes in solid argon. J. Phys. Chem. A 101, 3109-3118 (1997)

18. Chertihin, G.V., Andrews, L.: Infrared spectra of the reaction products of laser-ablated titanium atoms and oxides with carbon monoxide in solid argon. J. Am. Chem. Soc. 117, 1595-1602 (1995)

19. Aubriet, F., Chaoui, N., Chety, R., Maunit, B., Millon, E., Muller, J.-F.: Laser ablation mass spectrometry: a tool to investigate matter transfer processes during pulsed-laser deposition experiments. Appl. Surf. Sci. 186, 282-287 (2002)

20. Chéty-Gimondo, R., Aubriet, F., Millon, E., Muller, J.-F.: UV laser ablation of $\mathrm{GdCa}_{4} \mathrm{O}\left(\mathrm{BO}_{3}\right)_{3}$ ( $\mathrm{GdCOB}$ ) investigated by Fourier transform ion cyclotron resonance mass spectrometry. Rapid Commun. Mass Spectrom. 18, 2939-2945 (2004)

21. Pangavhane, S. D., Houska, J., Wagner, T., Pavlista, M., Janca, J., Havel, J. Laser ablation of ternary As-S-Se glasses and time-of-flight mass spectrometric study. Rapid Commun. Mass Spectrom. 24, 846 95$102(2010)$

22. Gauthier, J.W., Trautman, T.R., Jacobson, D.B.: Sustained off-resonance irradiation for collision-activated dissociation involving Fourier transform mass spectrometry. Collision-activated dissociation technique that emulates infrared multiphoton dissociation. Anal. Chim. Acta 246, 211-225 (1991)

23. Aprà, E., Windus, T.L., Straatsma, T.P., Bylaska, E.J., de Jong, W., Hirata, S., Valiev, M., Hackler, M., Pollack, L., Kowalski, K., Harrison, R., Dupuis, M., Smith, D.M.A., Nieplocha, J., Tipparaju, V., Krishnan, M., Auer, A.A., Brown, E., Cisneros, G., Fann, G., Fruchtl, H., Garza,
J., Hirao, K., Kendall, R., Nichols, J., Tsemekhman, K., Wolinski, K., Anchell, J., Bernholdt, D., Borowski, P., Clark, T., Clerc, D., Dachsel, H., Deegan, M., Dyall, K., Elwood, D., Glendening, E., Gutowski, M., Hess, A., Jaffe, J., Johnson, B., Ju, J., Kobayashi, R., Kutteh, R., Lin, Z., Littlefield, R., Long, X., Meng, B., Nakajima, T., Niu, S., Rosing, M., Sandrone, G., Stave, M., Taylor, H., Thomas, G., van Lenthe, J., Wong, A., Zhang, Z.: NWChem, A Computational Chemistry Package for Parallel Computers, 47th edn. Pacific Northwest National Laboratory, Richland (2005)

24. Aubriet, F., Muller, J.-F.: Laser ablation mass spectrometry of inorganic transition metal compounds. Additional knowledge for the understanding of ion formation. J. Am. Soc. Mass Spectrom. 19, 488-501 (2008)

25. Aubriet, F., Gaumet, J.-J., de Jong, W.A., Groenewold, G.S., Gianotto, A.K., Mcllwain, M.E., Van Stipdonk, M.J., Leavitt, C.M.: Cerium oxyhydroxide clusters: formation, structure, and reactivity. J. Phys. Chem. A 113, 6239-6252 (2009)

26. Gianotto, A.K., Rawlinson, J.W., Cossel, K.C., Olson, J.E., Appelhans, A.D., Groenewold, G.S.: Hydration of alumina cluster anions in the gas phase. J. Am. Chem. Soc. 126, 8275-8283 (2004)

27. Gowtham, S., Lau, K.C., Deshpande, M., Pandey, R., Gianotto, A.K., Groenewold, G.S.: Structure, energetics, electronic, and hydration properties of neutral and anionic $\mathrm{Al}_{3} \mathrm{O}_{6}, \mathrm{Al}_{3} \mathrm{O}_{7}$, and $\mathrm{Al}_{3} \mathrm{O}_{8}$ clusters. $J$. Phys. Chem. A 108, 5081-5090 (2004)

28. Scott, J.R., Groenewold, G.S., Gianotto, A.K., Benson, M.T., Wright, J.B.: Experimental and computational study of hydration reactions of aluminum oxide anion clusters. J. Phys. Chem. A 104, 7079-7090 (2000)

29. Groenewold, G.S., Scott, J.R., Gianotto, A.K., Hodges, B.D.M., Kessinger, G.F., Benson, M.T., Wright, J.B.: Gas-phase condensation reactions of $\mathrm{Si}_{\mathrm{x}} \mathrm{O}_{\mathrm{y}} \mathrm{H}_{\mathrm{z}}^{-}$oxyanions with $\mathrm{H}_{2} \mathrm{O}$. J. Phys. Chem. A 105, 9681-9688 (2001)

30. Michiels, E., Gijbels, R.: Fingerprint spectra in laser microprobe mass analysis of titanium oxides of different stoichiometry. Spectrochim. Acta Part A 38, 1347-1354 (1983)

31. Michiels, E., Gijbels, R.: Cluster ion distributions and correlation with fragment valence in laser-induced mass spectra of oxides. Anal. Chem. 56, 1115-1121 (1984)

32. Chaoui, N., Millon, E., Muller, J.F.: Heteropolyatomic gas-phase species produced by laser ablation of lead titanate oxide, studied by laser microprobe mass spectrometry. Chem. Mater. 10, 3888-3894 (1998)

33. Aubriet, F., Maunit, B., Muller, J.-F. Studies on alkali and alkaline earth chromate by time-of-flight laser microprobe mass spectrometry and fourier transform ion cyclotron resonance mass spectrometry. Part I. Differentiation of chromate compounds. Int. J. Mass Spectrom. 198, 189-211 (2000)

34. Aubriet, F., Maunit, B., Muller, J.-F. Studies on alkali and alkaline earth chromate by time-of-flight laser microprobe mass spectrometry and Fourier transform ion cyclotron resonance mass spectrometry. Part II. Understanding cluster ion formation. Int. J. Mass Spectrom. 198, 213234 (2000)

35. Gianotto, A.K., Hodges, B.D.M., Benson, M.T., de Harrington, P.B., Appelhans, A.D., Olson, J.E., Groenewold, G.S.: Ion-molecule reactions of gas-phase chromium oxyanions: $\mathrm{Cr}_{\mathrm{x}} \mathrm{O}_{\mathrm{y}} \mathrm{H}_{\mathrm{z}}^{-}+\mathrm{H}_{2} \mathrm{O}$. J. Phys. Chem. A 107, 5948-5955 (2003)

36. Gianotto, A.K., Hodges, B.D.M., de Harrington, P.B., Appelhans, A.D., Olson, J.E., Groenewold, G.S.: Ion-molecule reactions of gas-phase chromium oxyanions: $\mathrm{Cr}_{\mathrm{x}} \mathrm{O}_{\mathrm{y}} \mathrm{H}_{\mathrm{z}}^{-}+\mathrm{O}_{2}$. J. Am. Soc. Mass. Spectrom. 14, 1067-1075 (2003)

37. Albaret, T., Finocchi, F., Noguera, C.: Ab initio simulation of titanium dioxide clusters. Appl. Surf. Sci. 144/145, 672-676 (1999) 